\begin{tabular}{lc}
\hline & ANNALES \\
& UNIVERSITATIS MARIAE CURIE-SKŁODOWSKA \\
LOL. V & SECTIO N \\
\hline
\end{tabular}

ISSN: 2451-0491 • e-ISSN: 2543-9340 - CC-BY 4.0 • DOI: 10.17951/en.2020.5.427-440

\title{
"Polish for Everyone". A Few Notes on the Oldest Textbooks for Learners of Polish in the Czech Republic ${ }^{1}$
}

\author{
„Polski dla każdego”. Kilka uwag na temat najstarszych \\ podręczników do nauki języka polskiego w Czechach
}

\author{
Renata Rusin Dybalska \\ Charles University. Department of Central European Studies \\ nám. Jana Palacha 2, 11638 Prague 1, Czech Republic \\ renata.dybalska@ff.cuni.cz \\ https://orcid.org/0000-0002-1738-5985
}

\begin{abstract}
Abstrakt. Opracowanie jest częścią aktualnie prowadzonych badań na temat początków nauczania języka polskiego w Czechach. Przeprowadzono analizę dwóch podręczników do nauki języka polskiego wydanych na przełomie XIX i XX wieku: Franciszka Vymazala Polský snadno a rychle (Praga 1896) oraz Franciszka Aloisa Hory Praktická mluvnice polská s čitankou (Praga 1901). Omówiono zarówno ich strukturę i zawartość, jak i zastosowane metody dydaktyczne. Wskazane publikacje oraz ich autorzy stanowią też źródło informacji na temat ówczesnych kontaktów czesko-polskich.
\end{abstract}

Slowa kluczowe: Czechy; podręczniki do nauki języka polskiego; Franciszek Vymazal; Franciszek Alois Hora

1 Polish for Everyone is the title of the textbook by Iza Šaunová (1930). The paper herein was prepared as part of the grant funded project: Česká univerzitní polonistika do roku 1939 (od polonofilství k systematickému bádání o dějinách polského jazyka a literatury) / Czech University Polish Studies before 1939 (from polonophilia to systematic research on the history of Polish language and literature), Grantová agentura České republiky / The Czech Science Foundation, No. 19-09017S. 


\begin{abstract}
The paper herein is part of the ongoing research on the beginnings of Polish language instruction in Czechia. It discusses two textbooks for learners of Polish published at the turn of the $19^{\text {th }}$ and $20^{\text {th }}$ centuries: Franciszek Vymazal's Polský snadno a rychle (Prague 1896) and Franciszek Alois Hora's Praktická mluvnice polská s ćitankou (Prague 1901). Their structure and contents are analysed together with applied teaching methods. Presented publications and their authors have become the source of information regarding the Czech and Polish relations at the time.
\end{abstract}

Keywords: Czech Republic; Polish language textbooks; Franciszek Vymazal; Franciszek Alois Hora

\title{
INTRODUCTION
}

In 2023, we will mark one hundred years since the first Institute of Polish Language and Literature was established outside Poland, in the Czech Republic. It started operating in October 1923 at the Charles University in Prague, headed by Professor Marian Szyjkowski (Benešová et al. 2013: 11-25). It was the institutional birth of Polish language instruction on the university level in the Czech Republic. It came into being as the result of long-term efforts and, more importantly, of the interest in Poland, Polish culture and language that had started long before.

This interest manifested itself, e.g. in teaching resources for learners of Polish that surfaced in the Czech Republic already in the first half of the $19^{\text {th }}$ century (Dąbrowska 2010: 49-58; Rusin Dybalska 2014: 238-246; Tarajło-Lipowska 2005: 323-333). The first one was the textbook by Dominik Alois Špachta published in Prague in 1837 under a very original title Pokus Čecha o naučeni se počátkům gramatiky jazyka polského, kterýs vlastenci svými sdili Dominik Špachta, farář v Kolči (Eng.: An Attempt by a Czech to Learn Basics of Polish as Shared with his Fellow Countrymen by Dominik Špachta, a Koleč Parish Priest). The publication had a number of reprints and for a long time served as a benchmark for other authors. And they were plenty. By 1939, more than 30 various teaching materials saw the light of the day, including all shapes and sizes of grammar textbooks (Vymazal 1881; Suchecki 1857), classic language textbooks (Paulík 1891; Vydra 1932), dictionaries (Hora 1890; Fuhrich 1925), but also phrasebooks (Vydra 1915) and books on Polish realities (Vydra 1928), many of whom were reprinted a number of times. They were penned both by Czechs and Poles who actively contributed to the development of Czech and Polish relations also in other ways. 
The paper herein presents two such publications ${ }^{2}$ from the turn of the $19^{\text {th }}$ and $20^{\text {th }}$ centuries, namely: Polský snadno a rychle (Vymazal 1896) and Praktická mluvnice polská s čítankou (Hora 1901).

\section{A POLYGLOT AND A POLONOPHILE}

The first of the titles discussed herein was written by Franciszek Vymazal (1841-1917) (for more on Vymazal, see e.g. František... 2008: 1546-1550; Gregor 1967: 44-55; 1959: 127-135), who spent most of his life in Brno. Although he never had any major problems as far as studying is concerned, his views and uncompromising attitude from his young age made it impossible for him to graduate from any school ${ }^{3}$. First, he worked as a private tutor, then as an editor and a journalist, and eventually his main activity became the work of the proof-reader for the Moravian Printing House (Moravská akciová tiskárna), where he worked for 28 years. However, it was only the background to his true calling, as he became much better known as the author of popular textbooks for learning foreign languages, promoting and verifying his teaching method that could be summarized in two words - snadno a rychle, i.e. "fast and easy". His first textbooks were published in the mid-1890s and were later supplemented and reprinted long after the death of their author; many came out in several editions. Being a self-taught polyglot (with active knowledge of 10 languages and passive of 28) Vymazal published more than 150 various types of books dedicated to 28 languages, including, e.g. Russian, German, Bulgarian, English, Spanish, Croatian, Romanian, but also Hungarian, Swedish, Turkish or Roma. According to Franciszek Backovsky, the Prague-based publisher of Vymazal's textbooks, the most popular titles among the readers were those promoting learning English, Italian and... Polish. His adventures in Polish the author commenced in 1881, when he published Gramatické základy jazyka polského (Vymazal 1881) (Eng.: Basics of Polish Grammar). His following work, Grammatik der polnischen Sprache, was published in 1884, while in 1896, the first edition of Polský snadno a rychle textbook came out.

The first of the discussed authors can be defined as a promoter of closer Czech-Slavonic relations, while the second was one of the most distinguished

2 Data presented herein are part and parcel of wider research of all publications of this type published in Czechia until 1939.

3 He, for example, refused to take his school-exit exam ("matura", or "maturity exam"), because he claimed that the exam did not test maturity in any way - for more on the topic, see A. Gregor, $O$ životě..., p. 128. 
advocates of developing Czech and Polish relations in his time. Franciszek Alois Hora (1863-1916) (for more on Hora, see e.g. František... 1993: 258-259; Suchá 1952/53: 322-337) made the centre of his interest in Poland the city of Pilsen, with which he remained associated for most of his life. He was a mathematician by education and read mathematics, e.g. first in Vienna, and later in already mentioned Pilsen. However, this paper shall mainly focus on his activities connected with Polish and Czech relations that symbolically began with the crushing defeat of the Polish 1863 January Uprising. Here for the first time one can refer to Hora as to a translator ${ }^{4}$ - he translated, for example, works of such authors as B. Grabowski, H. Sienkiewicz, J.I. Kraszewski, E. Orzeszkowa, B. Prus, T.T. Jeż or G. Zapolska. The exact number of his translations is not known, because very often he would not attach his name to the effects of his work. In reference materials one can trace their number to roughly one hundred. His translation work included inherently voluminous correspondence with various representatives of Polish cultural life, many of whom became his dear friends. Among the documents that survived him and are collected in Pilsen archives there are letters from Warsaw, Grodno, Lviv, Cracow, Gniezno, Łódź, Zakopane or Tarnów ${ }^{5}$. This unreserved fondness of Poland meant that Hora can be now referred to also as the author of works promoting the Polish language. The first one was a Polish-Czech (Hora 1890) and Czech-Polish dictionary (Hora 1902) that he self-published with the help of his Polish friends. It was later followed by two textbooks, Rukovět' konversace česko-polské (Hora 1887) (Eng.: Handbook of Czech and Polish Conversation) and Praktická mluvnice polská s čitankou (Hora 1901) (Eng.: Practical Polish Grammar and Reader).

\section{POLSKÝ SNADNO A RYCHLE - F. VYMAZAL}

The textbook discussed in this paper was first published in 1896 in Prague 6 . It is a part of the series of publications by Vymazal on foreign languages, consisting of 28 textbooks in total. In the foreword, the author briefly introduces the Polish language emphasizing that out of all Slavonic languages this one is the closest to Czech and the easiest one to understand for the Czech audience. In his short presentation he also mentions Moravian dialects that he refers to as intermediate

\footnotetext{
4 He translated not only from Polish, but also from German.

5 He took a trip to Poland himself and even wrote a guidebook on Cracow, Wieliczka and the region: F.A. Hora, Průvodce po Krakově, Věličce a okolí, Kolin 1884.

6 Subsequent editions followed in 1903 and 1916. The analysis herein is based on the last, third edition.
} 
stages between the Czech and Polish language and discusses mutual contacts between these languages. The second group of preliminary information, Polské čteni a psaní (Eng.: Reading and Writing in Polish), focuses on certain notes that are supposed to help the reader acquire the two competencies in the title. First of all, the most blatant differences are identified, namely no vowel length, existence of nasals, non-syllabic $l$ and $r$ (pp. 4-6), followed by practical notes, for example, that the best way to monitor proper reading is to seek help from a native Pole (p. 6) and some inspirational notes: he who can properly read the word zwycięzyt (past tense of "win"), can read Polish, which is already half the victory (p. 7). Finally, the author formulates the main goal of the textbook. It is to learn how to make simple sentences in the given language on everyday topics that will become the foundation for further study.

The content of the analysed publication is divided into 25 exercises (Czech: uloha). They can be grouped into three thematic sections according to their character and contents. The first one begins with the explanation of the teaching method applied in the textbook. The author delivers on his promise in the foreword and suggests to study by learning short, practical sentences the student is supposed to re-read until properly memorized. Additionally, he recommends that the students thoroughly rewrite them at least once. All sentences prepared by the author are always presented in both language versions, i.e. in Polish and in Czech and are a constant element of each exercise that the student is meant to complete.

The first thematic section is mainly focusing on grammar. It concentrates on the verb and the following verb-related topics: past tense (exercise 2), present tense (exercise 3, 4, 5), future tense (exercise 6), conditionals (exercise 7), imperative (exercise 8). Two final exercises are different in nature. Exercise number 9 is focusing on Polish forms of address. It includes sentences with different application of forms Pan (Mr.), Pani (Ms.), but also Pański, Pańska or Pańskie (possessive forms of Mr. and Ms.). The last exercise in this area is called egzamin ${ }^{8}$ (Eng.: a test), which is a revision and consolidation practice. The student is to quickly translate ten sentences into Polish. Should he or she find it difficult to complete, they are asked by the author to revise the topics covered in the first nine exercises.

The half of the second thematic section is also dedicated to grammar issues with declension as the main point of focus. The following parts of speech

7 These forms are always capitalized, regardless of their position in the sentence.

8 Not all exercises have a heading that would disclose the specific issue they refer to. Out of 25 exercises only 16 are introduced with a heading. 
are introduced: pronoun (exercise 11, 12, 13, 14) and adjective together with noun (exercise 15). The second group of points is dedicated to the reading skill. Subsequent exercises present texts that are meant to help the student master this competency. The texts represent various genres, e.g. a joke (exercise 16), a proverb (exercise 17) or an anecdote (exercise 18). Two of them, however, are special in their character. In exercise 16, the texts of original signboards from the streets of Cracow sent by Michał Chyliński ${ }^{9}$ to the author are used. Thus, for a moment the readers feel as if they were in Poland, but more importantly, they are convinced they are studying real, living, modern language. One should mention that the more challenging words selected by the author are accompanied by their Czech equivalents placed directly thereafter in brackets. Exercise 19 includes a fragment of Večerní písně (Eng.: Evening Songs) by Vítězslav Hálek (1859) in the Polish translation by Władysław Bełza, with additional comments by the author, some of them critical. The second thematic section also ends with the test (exercise 20). This time the student is asked to translate 14 sentences. To facilitate the task, Czech equivalents of some Polish words are introduced in brackets. One should add that this time the author decides to provide the correct translation directly under the exercise.

The third thematic section is the shortest. It consists of two grammatical points, namely the plural ${ }^{10}$ (exercise 21 ) and numerals (exercise 22, 23). Exercise 24 is dedicated to date and time format. Apart from the practical use of numeral forms the student additionally learns extra vocabulary, i.e. the names of the months. The final $25^{\text {th }}$ exercise contains the third test. The students are asked to translate 11 sentences here. They can compare the outcome of their work with the translation by the author presented underneath.

The last part of the analysed textbook includes short Czech-Polish dialogues. They are made of useful sentences and phrases, for example, vycházka (on a walk), $v$ hotelu (in the hotel), u lékaře (at the doctor's), u obuvníka (at the cobbler's), $v$ knihkupectví (in a bookstore), na nádraží (at the train station) or při cestování (travelling). As a supplement to the resources the author recommends his second, newly published textbook on speaking this time, namely Čech s Polákem rozmlouvající (Vymazal 1913) (Eng.: A Czech Talks to a Pole).

The afterword included at the end of the book presents a set of guidelines and suggestions for students. We learn, for example, that the best friend of each learner of Polish is a good dictionary and good contemporary literature. When writing about literature Vymazal refers to the work of such authors as

\footnotetext{
9 The reader learns this from the footnote.

10 It relates to the forms of nouns, pronouns and numerals.
} 
H. Sienkiewicz, J.I. Kraszewski, T.T. Jeż or E. Orzeszkowa to name a few. He additionally encourages students to jot down more difficult words when reading and to motivate them to do so, he presents his own sample list. Finally, he proposes the final exercise, namely the list of selected words that the student should try to find on his or her own in the dictionary.

\section{PRAKTICKÁ MLUVNICE POLSKÁ S ČÍTANKOU - F.A. HORA}

The textbook discussed was first published in Prague in $1901^{11}$. The publication is dedicated to Erazm Majewski ${ }^{12}$. In the foreword, dated 1 August 1900, the author introduces his work in a few words. He believes his textbook to be a good reference for learning Polish, because it presents in a clear, concise and illustrative way the rules of Polish grammar. Grammatical points are complemented with exercises, a glossary and a short reading exercise. The author recommends that thorough students complete exercises in writing with the help of his two previous books, namely the dictionary (Hora 1890, 1902) and a speaking textbook (Hora 1887). Finally, he mentions what were the models he followed when preparing his work. These were four Polish textbooks, namely: Gramatyka jezyka polskiego (Eng.: Polish Grammar) by A.A. Kryński (1897), Gramatyka polska w zarysie popularnym (Eng.: Concise Polish Grammar) by A.G. Bem (1889), Gramatyka jezyka polskiego (Eng.: Polish Grammar) by A. Jeske (1900) and Gramatyka języka polskiego szkolna (Eng.: Polish Grammar for Schools) by A. Małecki (1882).

The language points start with information about pronunciation. In general notes, the author focuses mainly on differences between the two languages. Thus, the reader learns, e.g. that Polish no longer has vowel length and that vowels $l$, $m, n, r$ are non-syllabic. In the detailed section, he covers in alphabetical order all sounds. Apart from examples of specific words he also includes references to other languages, first and foremost to Czech, but also to French, German or Upper Lusatian. Next, a short chapter deals with the accent. Here one finds not only the discussion of main rules of stressing syllables, but also points on exceptions. This first short section ends with reading practice. The author includes here selected proverbs and a short text about a lutenist at the court of

11 The analysis herein is based on this edition. Next editions were published as follows: $2^{\text {nd }}$ edition in 1909, $3^{\text {rd }}$ edition in 1915.

12 Erazm Majewski (1858-1922), an archaeologist, a biologist, a sociologist, a philosopher, an economist, an ethnographer and a novelist. He helped Hora raise funds for the publication of his dictionary and organized distribution of the publication in Poland. The second edition of the discussed book was dedicated to Konrad Zaleski (1851-1921) who was a translator of Czech literature, a poet, a columnist and a social activist, a friend of Hora. 
King Sigismund Augustus. One should mention that all texts are presented in both language versions, namely in Polish and in Czech.

The next chapter focuses on the auxiliary verb być (Eng.: to be). All presented forms of the verb in question, namely the present, the future and the past tense, and participles are provided with usage examples in specific sentences. The role of these examples is twofold, because they become also the starting point for the discussion of other related grammar questions, such as inflection endings of adjectives or moveability of past tense markers. There are also notes on other points, e.g. the student learns how to form yes/no questions starting with $c z y$. The section ends with practice helping acquire skills of composing simple questions, creating negative forms or translating sentences from Czech into Polish.

The next section of the textbook deals with comparison of adjectives. It is based on a similar concept: first, the discussion of general rules, exceptions, followed by the presentation of specific forms in examples. This time the practice includes, apart from translation tasks, also a fragment of the poem by Teofil Lenartowicz Jak to na Mazowszu (Eng.: On Life in Mazovia).

The following chapters of the textbook are arranged according to a key in the form of speech parts. And thus, the points on verbs, nouns combined with adjectives, pronouns, numerals, adverbs, prepositions, conjunction and interjection follow.

The first of these parts of speech is covered most extensively. Five conjugations are presented and identified based on the form of the root in the present tense: I - suffix -e (niesie, bierze), II - suffix -nie (ciśnie, pragnie), III - suffix -je (bije, siwieje), IV - suffix - $i$ (wozi, broni), V - suffix - a (dba, ufa). In some cases, due to different infinitive forms, additional sub-patterns are identified: I -3 patterns, III -4 patterns, IV -2 patterns. Each class is described in the same format: first, the conjugation of the sample verb in the present tense and in the imperative mood, list of other forms (participles, infinitive, verbal noun), followed by detailed notes on more challenging or unusual forms, practice (usually conjugation of selected verbs or completing indicated sentences with proper forms of verbs). The detailed discussion is preceded by the section on three verbs - wiem, jem and dam (I know, I eat, I will give). On their example, complex tense forms are discussed, namely past, past perfect, future, conditionals and passive voice. Additionally, there are explanatory notes for the reader on impersonal forms of verbs and the use of pan/pani (Mr./Ms.).

The nouns are discussed together with adjectives arranged according to their grammatical gender, namely masculine, feminine and neuter. The student can find declension patterns for sample words together with the discussion of the use of individual endings and practice for the revision of the given form. This 
chapter addresses three additional points. The first one is about declension of gerunds with three identified groups (1 - inflect like an adjective, e.g. gajowy, woźny, 2 - mixed declension pattern, e.g. choraży, podkomoży, 3 - inflect like a noun, e.g. hrabina, królewna). The second point focuses on possessive nouns, such as ojców, matczyn, Zosin (Eng.: offather, of mother, of Zosia), while the last one deals with the dual number.

In the discussion of pronouns the main criterion is the meaning. Following the well-known formula, the chapter presents personal, possessive, demonstrative, interrogative, relative and indefinite pronouns together with declension patterns, notes and practice. In the next section, numerals are discussed, starting with a list of forms of cardinal and ordinal numbers which is then enhanced with notes on individual declension patterns. Information about collective, fractional and manifold numerals is provided as well. Adverbs are divided into seven groups (manner, time, place, reason, degree and frequency, interrogative, affirmative, negative or expressing doubt). The comparison rules for regular and irregular adverbs is detailed. Prepositions are presented in two groups, depending on the case they take or the function they have as a prefix. The type of conjunction depends on the type of sentence it is used in (e.g. copulative, disjunctive, adversative, conditional, consecutive), while interjections are presented in three groups, depending on whether they express emotions, sounds of nature or other sounds. The final part of the reference guide is dedicated to Polish syntax.

As already announced by the title, the final part of the textbook is the reader. The students can find here not only reading materials (poetry ${ }^{13}$, prose ${ }^{14}$, selected aphorisms ${ }^{15}$ ), but also sample practical writing (a letter, an order slip, a receipt).

Since the time that passed between the publication of the discussed textbooks is negligible, one can assume they were developed practically simultaneously. They are both addressed to the same audience, namely Czechs who want to learn Polish, however, each seems to propose a slightly different way of reaching this desired goal. Hora's Grammar is a classic textbook based on the grammar-translation method widely applied at the time. Already in the beginning, it refers to model Polish textbooks, and it is enough to complete a quick comparative study, e.g.

13 Cf. works by H. Wróblewski, B. Grabowski.

14 Cf. works by B. Prus, Cz. Jankowski, K. Tańska Hoffmanowa, J.I. Kraszewski.

15 Authors, e.g.: M. Bałucki, J. Bliziński, S. Goszczyński, J.Ch. Pasek. 
with the mentioned textbook by A.A. Kryński to see that the author sometimes followed these models almost to the letter, e.g. by providing declension patterns for the same words (e.g. a masculine noun - maż, gość, koń, kraj, krzyż; Eng.: man, guest, horse, country, cross [p. 67]), sometimes adapting them to his own objectives or rather to his audience (e.g. by explaining the complexities connected with the ending of the genitive case in singular for masculine nouns, $a$ or $u$ [pp. 67-69] and always providing both forms of the noun, namely the basic nominative form and the genitive form; the first one is not provided in the Polish model textbook) ${ }^{16}$. Open use of model textbooks shows that the author knows the subject matter well and is well informed about the reference materials. In that sense the author seems to be confident about himself and his expertise. The student finds out already in the first sentence (p. 1) that the book will definitely serve him or her well. The textbook also provides notes on current changes in Polish, e.g. the information that the past perfect tense use is very limited (p. 27) as well as possessive forms of nouns, such as matczyn, ciotczyn, Zosin (English: of mother, of aunt, of Zosia) (pp. 84-85); it includes practical suggestions which prove author's experience in teaching Polish ${ }^{17}$, e.g. on page 13 one learns that the verb to be in the $3^{\text {rd }}$ person singular is sometimes omitted, so that instead of saying To jest prawda one would say To prawda, while on p. 92 the author advises that you should answer the question Czyja to ksiażka? (Eng.: Whose book is this?) with one word only - moja (Eng.: mine). This apt marriage of theory with practice seems to be the main task that Hora undertook to fulfil. Thoroughly discussed rules of Polish grammar are accompanied by practice, mainly consisting of translation, but also of gap filling or providing correct forms, alternatively of sentence transformation. Thanks to additional examples of use included in addressed points some of them get as if organically associated, e.g. when an example illustrating one issue becomes the starting point to cover another rule, see e.g. discussion of adjective case inflection endings in the entry on verb to be conjugation in the present tense (pp. 12-13). The reader included in the textbook is meant as extra practice for the learners. As proof that the author put great emphasis on practice let us refer to the second edition of the publication from 1909, which was enhanced against the original version with extra practice and additional texts in the reader. One should also point out that there are elements of the comparative method applied in the book as well. Frequent

16 Examples from the comparison come from the textbook by A.A. Kryński, Gramatyka języka polskiego, Warszawa 1900 ( $2^{\text {nd }}$ edition); declension patterns - p. 50, information about the genitive singular ending - pp. 52-56.

17 For many years the author was providing Polish instruction in Pilsen free of charge. 
comparisons with Czech are only natural and understandable ${ }^{18}$, but apart from Czech also other - not only Slavonic - languages become the point of reference.

Vymazal's textbook on the other hand, although also following the prevailing grammar-translation method, suggests the use of a teaching method that limits theory to the necessary, in author's view, minimum. He proposes his own method, applied not only in the textbooks he prepared for teaching foreign languages ${ }^{19}$, a method that was supposed to be first and foremost fast and easy. It was based on simple sentences, used in everyday communication, that were to be memorized, e.g.: Dziś jest piatek (English: It's Friday today), To jest $z a$ mało (English: That's not enough) (p. 10), Nie rób głupstw (English: Let's not do anything silly), Chodźmy do ogródka (English: Let's go to the garden) (p. 19), Znatem go dobrze (English: I knew him well), Styszałem coś o niej (English: I heard something about her) (p. 24). The role of these sentences is twofold: they are an indicator of the given grammar rule, but also they present a corpus of essential vocabulary. Unlike the textbook by Hora, Vymazal's work does not provide any additional glossaries, because the short conversations at the end of the book are there to fill in this role. This broadly defined practice is reflected also in the very unique rapport between the author and his audience: they seem to be in a dialogue of sorts. This rapport is based mostly on the permanent contact and motivation to further study of the resources in the form of follow-up questions, such as Jak vyslovime slova: ojciec, gdzie, dziś? (Eng.: How do you pronounce words: father, where, today?) (p. 11), Matku je matkę, školu szkote [...] Proč? (Eng.: Matku means matka (mother), školu means szkota (school) [...] Why?) (p. 13); good advice: Velmi mnoho se nauči ten, kdo vyhledá si Poláka a hovoři s nim. Dávej pozor, cos mluvil. Zápis si takové věty, dej si je od Poláka přeložiti a nauč se jim nazpamét (Eng.: He who finds himself a Pole to talk to will learn a lot. Be careful of what you say. Write down such sentences, give them to a Pole for translation and memorize them) (p. 21); and some justifications and requests for feedback - Ne vím, jak se Vám dvě předešle úlohy líbily [...] Jedna knízka nemůže hověti všem. Nejlépe by bylo, kdyby si mohl každý dat napsat knižku, jaká se mu nejvice hodi (p. 24) (Eng.: I don't know how you liked the two previous sentences [...] One book cannot appeal to everyone. Ideally one would wish to write a book that would suit this particular person). All this leads to bridging the gap between both parties in this communication, and the author turns in

18 One should also mention that Hora penned a Czech language coursebook for Poles: F.A. Hora, Praktyczna metoda języka czeskiego. Gramatyka, ćwiczenia, rozmówki (English: Practical Czech Method. Grammar, Practice, Phrasebook), Lwów 1909.

19 He applied the very same method in his trigonometry and algebra textbooks as well. 
fact into a friend of the student rather than a teacher. This unique approach to the traditional interpretation of theoretical issues is also shown in the amount of space that the author decides to dedicate to specific points, e.g. the verb and its forms are covered by nine exercises with three devoted to present tense, four exercises cover forms of pronouns, but neither is dedicated exclusively to forms of nouns. The nouns are discussed only in combination with adjectives, pronouns and numerals. The author is very selective in terms of presented forms, e.g. the student not always has the option to learn all case forms of the given word. Suggested translations of provided sentences also seem rather disputable, as they sometimes seem to literal, e.g.: Będzie wnet deszcz padać / Bude hned pršet (p. 17) (Eng.: It will rain now); Gdzie byteś Pan tak dtugo? / Kde jste byl tak dlouho? (p. 20) (Eng.: Where have you been so long, sir?); Trzy kwadranse na piąta / Tři čtvrtí na pátou (Eng.: Three quarters past four) (p. 37).

Both analysed textbooks focus more on fluent reading and proper pronunciation. The authors recommend developing writing competency as well, however, they leave it to the good will and motivation of the learner. And here is where the similarities between the two seem to end. Grammar, so crucial for Hora, is only an addition for Vymazal and seems to be a secondary issue ${ }^{20}$. Maybe it is due to the fact that the author already in the beginning stresses that his textbook provides students with essential basics for further study.

The books discussed are undoubtedly documents of their time. Today they have only a historic value, but their role in this history is undeniably manifold. First of all, they are a direct proof of interest in the Polish language in the Czech Republic at the turn of the $19^{\text {th }}$ and $20^{\text {th }}$ centuries. This was the reason and also the result of intense Czech-Polish contacts not only in the linguistic sphere, but also on the personal level, where the authors of the textbooks discussed played one of the key roles. They both cultivated more or less close relations not only with leading figures of Polish literature at the time, but also with linguists ${ }^{21}$. Finally, the books present an interesting and significant contribution to the history of teaching Polish as a foreign language in the country where the first Institute of Polish Studies abroad was established at the university level.

20 As it has been already mentioned, Vymazal also wrote a grammar textbook.

21 Hora, for example, corresponded with B. Grabowski, J. Karłowicz, W. Gomulicki, J.I. Kraszewski, G. Zapolska or E. Orzeszkowa, while Vymazal kept in touch with J. Baudouin de Courtenay. 


\section{REFERENCES}

Bem, A.G. (1889). Gramatyka polska w zarysie popularnym. Warszawa: Gebethner i Wolf.

Benešová, M., Rusin Dybalska, R., Zakopalová, L. (2013). 90 let pražské polonistiky dějiny a současnost. 90 lat praskiej polonistyki - historia $i$ wspótczesność. Praha: Karolinum.

Dąbrowska, A. (2010). Z Czego Czesi uczyli się języka polskiego w XIX w. In: J. Miodek, W. Wysoczański (red.), Rozprawy Komisji Językowej XXXVII (pp. 49-58). Wrocław: Wrocławskie Towarzystwo Naukowe.

František Alois Hora. (1993). In: V. Forst (ed.), Lexikon české literatury (Vol. 2; pp. 258 259). Praha: Academia.

František Vymazal. (2008). In: L. Merhaut (ed.), Lexikon české literatury (Vol. 4; pp. 15461550). Praha: Academia.

Fuhrich, J. (1925). Diferenční slovník polsko-český. Praha: J. Fuhrich.

Hálek, V.J. (1859). Večerní písně. Praha: Antonin Renn.

Hora, F.A. (1884). Průvodce po Krakově, Věličce a okolí. Kolin: Pak a Nedvídek.

Hora, F.A. (1887). Rukovět' konversace česko-polské. Praha: A. Storch.

Hora, F.A. (1890). Kapesni slovník polsko-český. Praha: A. Storch.

Hora, F.A. (1901). Praktická mluvnice polská s čítankou. Praha: Houser (2 $2^{\text {nd }}$ edition, $1909 ; 3^{\text {rd }}$ edition, 1915).

Hora, F.A. (1902). Kapesni slovník česko-polský. Praha: Řivnáč.

Hora, F.A. (1909). Praktyczna metoda języka czeskiego. Gramatyka, ćwiczenia, rozmówki. Lwów: Poloniecki.

Gregor, A. (1959). O životě a díle spisovatele Františka Vymazala. Vlastivědný věstník moravský, vol. 14, 127-135.

Gregor, A. (1957). František Vymazal jako filolog. Vlastivědný věstník moravský, vol. 19, $44-55$.

Jeske, A. (1900). Gramatyka jezzyka polskiego. Warszawa: Michał Arct.

Kryński, A.A. (1897). Gramatyka jezyka polskiego. Warszawa: Jan Jeżyński.

Małecki, A. (1882). Gramatyka języka polskiego szkolna. Lwów: E. Winiarz.

Paulík, J. (1891). Učebnice jazyka polského se zvláštním zřením k výslovnosti, obsahujicí mluvnici, rozmluvy a čítanku. Pro školy i samouky. Praha: Dr. Fr. Bačkovský.

Rusin Dybalska, R. (2014). Z dějin výuky polštiny v Čechách. Několik slov o „Učebnici polštiny pro posluchače kursů polského kulturního střediska v Praze" (1961-1968). In: M. Benešová, R. Rusin Dybalska, L. Zakopalová (eds.), Proměny polonistiky: tradice a výzvy polonistických studií (pp. 238-246). Praha: Karolinum.

Suchá, M. (1952/53). Písemné styky prof. F.A.H. s Poláky. Slavia, vol. 21, 322-337.

Suchecki, H. (1857). Zwięzta gramatyka polska od ces. król. Ministerstwa Oświecenia zalecona do użytku w szkołach ludowych. Kurs niższy. Praha: Fryderyk Rohlíčka.

Šaunová, I. (1930). Polština pro každého. Praha: Masarykův Lidovýchovný.

Špachta, D.A. (1837). Pokus Čecha o naučení se počátkům gramatiky jazyka polského, kterýs vlastenci svými sdíli Dominik Špachta, farářv Kolči. Praha: Wáclaw Špinka. 
Pobrane z czasopisma Annales N - Educatio Nova http://educatio.annales.umcs.pl Data: 26/04/2023 11:41:31

Tarajło-Lipowska, Z. (2005). Jak uczyć Czechów języka polskiego? In: M. Dąbrowska (red.), Jezyk trzeciego tysiaclecia III (T. 3; pp. 323-333). Kraków: Tertium.

Vydra, B. (1915). Hovory česko-polské. Praha: Jos. R. Vilímek.

Vydra, B. (1928). Současné Polsko. Praha: Vesmír.

Vydra, B. (1932). Učebnice polštiny. Praha: Československá grafická Unie.

Vymazal, F. (1881). Gramatické základy jazyka polského. Brno: Karel Winiker (2 $2^{\text {nd }}$ edition, 1884).

Vymazal, F. (1884). Grammatik der polnischen Sprache. Brno: Winkler \& Wehowski.

Vymazal, F. (1896). Polský snadno a rychle. Praha: Dr. Fr. Bačkovský.

Vymazal, F. (1913). Čech s Polákem rozmlouvajicí. Praha: Dr. Fr. Bačkovský. 